\title{
PERILAKU MASYARAKAT PADA RUANG TERBUKA PUBLIK DI KAMPUNG KEBANGSREN SURABAYA
}

\author{
M. Nu'man Al Ghifari \\ Departemen Arsitektur, Universitas \\ Pembangunan Nasional "Veteran" Jawa \\ Timur, \\ e-mail: $\underline{\text { nmnalghifari@gmail.com }}$ \\ Syam Zaki Firdausan \\ Departemen Arsitektur, Universitas \\ Pembangunan Nasional "Veteran" Jawa \\ Timur \\ e-mail: madaharsarch@gmail.com
}

\begin{abstract}
ABSTRAK
Kampung Kebangsren adalah perkampungan yang terletak di tengah kota Surabaya, yang dikelilingi oleh kawasan perkantoran, pusat perbelanjaan dan kawasan perhotelan. Kawasan Kampung Kebangsren tumbuh semakin padat, sehingga ruang terbuka semakin berkurang luasnya. Padahal keberadaan ruang terbuka sangat dibutuhkan untuk menunjang aktivitas dengan skala yang besar guna memenuhi kebutuhan bersama warga kampung. Penelitian ini bertujuan untuk mengidentifikasi pola pemanfaatan ruang terbuka dan faktor-faktor pembentuk ruang terbuka di kawasan Kampung Kebangsren. Metode penelitian yang digunakan adalah Behavioural Mapping, dengan melakkan survei lokasi dan mendokumentasikan pola kehidupan masyarakat Kampung Kebangsren untuk kemudian dianalisis dengan metode deskriptif kualitatif. Hasil penelitian adalah bahwa Kampung Kebangsren memiliki hubungan bermasyarakat yang erat, sehingga keterbatasan lahan tidak menjadi masalah utama, dimana masyarakat Kampung Kebangsren tetap mampu mengelola lahan yang sedemikian rupa menjadi sebuah ruang terbuka yang optimal dengan cara-cara yang cerdas.
\end{abstract}

KATA KUNCI: kampung kota, ruang terbuka, perilaku masyarakat, behavioral mapping

\section{PENDAHULUAN}

Perkembangan dan pertumbuhan suatu wilayah berdampak terhadap pertumbuhan dan kepadatan penduduk. Hal ini akan membawa konsekuensi spasial bagi kehidupan kota, yaitu adanya tuntutan ruang public dalam rangka pemenuhan kebutuhan penduduk. Constantinos A. Doxiadis menyebutkan bahwa perkembangan perumahan permukiman (development of human settlement) dipengaruhi oleh beberapa faktor yaitu:

1. Growth of density (Pertambahan jumlah penduduk)

Pertambahan jumlah penduduk akan membawa masalah baru. Secara manusiawi setiap keluarga ingin menempati rumah milik sendiri. Dengan demikian bertambah jumlah penduduk berakibat semakin bertambah jumlah hunian, dan berdampak semakin padatnya permukiman.

\section{Urbanization (Urbanisasi)}

Daya tarik pusat kota akan menyebabkan arus migrasi desa ke kota maupun dari luar kota ke pusat kota.

Pertumbuhan penduduk yang meningkat setiap tahunnya, juga akan menimbulkan kesenjangan antara kebutuhan tempat hunian dengan ketersediaan ruang publik, termasuk di dalamnya adalah penyediaan sarana dan prasarana serta pelayanan umum (Todaro, 2004). Ruang publik termasuk ketersediaan sarana prasarana menjadi penting dalam setiap perencanaan pembangunan permukiman, apalagi bila berada di pusat kota. Keberadaan ruang publik adalah untuk menunjang aktivitas dan kebutuhan penduduk serta menjadi ruang bagi masyarakat untuk berinteraksi, sehingga tidak menghambat hubungan sosial dalam bermasyarakat bagi warga Kampung Kebangsren.

\section{KAIIAN PUSTAKA}

Kampung kota adalah sebuah perkampungan di pusat kota yang menjadi sebuah ciri khas dari permukiman Indonesia. Kampung kota umumnya masih membawa karakteristik perilaku masyakat Indonesia, diantaranya rasa kekeluargaan dan sifat gotong royong yang masih terikat satu sama lain sesama warganya.

Pengertian kampung kota menurut beberapa ahli didefinisikan sebagai berikut:

1. Kampung merupakan kawasan hunian masyarakat berpenghasilan rendah dengan kondisi fisik kurang baik (Budiharjo, 1992).

2. Kampung merupakan kawasan permukiman kumuh dengan ketersediaan sarana umum buruk atau tidak ada sama sekali, kerap kawasan ini disebut "slum" atau "squater" (Turner, 1972)

3. Kampung merupakan lingkungan tradisional khas Indonesia, ditandai ciri kehidupan yang terjalin dalam ikatan kekeluargaan yang erat. Kampung kotor yang merupakan bentuk permukiman yang 
unik, tidak dapat disamakan dengan „slum" dan "squater" atau juga disamakan dengan permukiman penduduk berpenghasilan rendah (Hendrianto, 1992).

4. Kampung adalah unik, karena merepresentasikan kekhasan sejarah, kemampuan, usaha, perjuangan, dan bahkan jiwa merdeka warganya; kekhasan pada aspek fisik terletak pada pola-pola fisik yang beragam, organik, sering kali surprising, (Setiawan, 2010)

Pada dasarnya kampung kota cenderung sepert permukiman kumuh, dengan ketersediaan fasilitas umum dan ruang terbuka yang minim. Hal ini terjadi dikarenakan pertumbuhan penduduk dan urbanisasi yang semakin meningkat berdampak permukiman tumbuh semakin padat.

\section{Ruang Publik}

Ruang terbuka merupakan ruang yang direncanakan karena kebutuhan akan tempat-tempat pertemuan dan aktivitas bersama di udara terbuka. Dengan adanya pertemuan bersama dan relasi antara orang banyak, kemungkinan akan timbul berbagai macam kegiatan di ruang umum terbuka tersebut. Sebetulnya ruang terbuka merupakan jenis dari ruang umum (Eko Budiharjo, Djoko Sujarto, 2005, p. 89).

Keberadaan ruang terbuka mempertimbangkan beberapa aspek untuk menunjang keberlangsungan aktivitas di dalamnya, diantaranya aspek comfort, relaxation, passive angagement, active angagement, dan discovery.

1. Comfort, merupakan salah satu syarat mutlak keberhasilan ruang publik. Seberapa lama seseorang tinggal atau berada di ruang public, maka dapat dijadikan tolak ukur comfortable tidaknya suatu ruang publik.

2. Relaxation, merupakan aktivitas yang erat hubungannya dengan psychological comfort. Suasana rileks mudah dicapai jika badan dan pikiran dalam kondisi sehat dan senang.

3. Passive engagement, aktivitas ini sangat dipengaruhi oleh kondisi sekitar. Kegiatan pasif dapat dilakukan dengan cara duduk-duduk atau berdiri sambil melihat aktivitas yang terjadi di sekelilingnya atau melihat pemandangan berupa taman, air mancur, patung atau karya seni lainnya.

4. Active engagement, suatu ruang publik dikatakan berhasil jika dapat mewadahi aktivitas kontak/ interaksi antar anggota masyarakat (teman, famili atau orang asing) dengan baik.

5. Discovery, Merupakan suatu proses mengelola ruang publik agar di dalamnya terjadi suatu aktivitas yang tidak monoton.

\section{Jenis Ruang Terbuka}

Haryati (2008) menjelaskan bahwa ruang terbuka publik dapat berupa landscape (ruang terbuka hijau) maupun ruang terbuka terbangun, dengan kategori sebagai berikut:

1. Ruang terbuka publik skala lingkungan dengan luas dan lingkup pelayanan kecil, seperti ruang sekitar tempat tinggal (home oriented space), dan ruang terbuka lingkungan (neighbourhood space) (Rapuano, 1964).

2. Ruang terbuka publik skala bagian kota yang melayani beberapa unit lingkungan, seperti taman umum (public park), ruang terbuka untuk masyarakat luas (community space).

3. Ruang terbuka publik dengan fungsi tertentu, seperti ruang sirkulasi kendaraan (jalan raya/ freeway, jalan arteri, dan sebagainya), ruang terbuka publik di pusat komersial (area parkir, plaza, dan mall), ruang terbuka publik kawasan industri, dan ruang terbuka publik peringatan (memorial) (Carr dalam Darmawan, 2018).

4. Pasar terbuka publik (markets), yaitu ruang terbuka publik atau jalan yang digunakan untuk PKL (Pedagang Kaki Lima), bersifat temporer pada ruang yang ada seperti taman, daerah pinggir jalan, atau area parkir (Carr dalam Darmawan, 2018).

\section{Perilaku di Ruang Publik}

Manusia hidup dalam waktu maupun ruang dimana antara keduanya saling berinteraksi dan mempengaruhi. Bahkan dalam kondisi tradisional, ruang, waktu, makna, dan komunikasi saling berketerkaitan.

Perbedaan individual dalam perilaku spasial juga banyak dipengaruhi oleh faktor-faktor lainnya, seperti: budaya, usia, jenis kelamin, dan lain-lain. Meskipun demikian secara agregatif bahwa jarak-jarak tertentu bisa dipakai pada jenis-jenis hubungan tertentu. Tingkat keagregatan tersebut menurut Chermayeff dan Alexander dalam Deddy Halim (Hantono,2019) bisa dilihat dari tingkatan ruang personal menuju ruang publik yang memiliki 6 (enam) spektrum :

1. Daerah pribadi perorangan, berhubungan dengan satu individu (ruang personal).

2. Daerah pribadi keluarga atau kelompok kecil, berhubungan dengan kelompok (rumah tangga, asrama, dan sebagainya).

3. Daerah pribadi kelompok besar, berhubungan dengan kelompok sekunder (manajemen pengelolaan privasi atas nama semua penghuni dalam suatu bangunan).

4. Daerah publik kelompok besar, meliputi interaksi kelompok besar dengan publik (kaki lima dalam suatu lingkungan yang dikontrol jam bukatutupnya dan jalan lingkungan).

5. Daerah semi publik perkotaan, yang diawasi pemerintah atau institusi dengan akses masuk 
untuk publik sesuai dengan kebutuhan (bank, kantor pos, pelabuhan udara, balai kota).

6. Daerah publik perkotaan, ditandai dengan kepemilikan umum dan akses publik sepenuhnya (taman, mal, dan jalan raya).

Ruang personal bersifat dinamis dan dimensi yang bisa berubah. Orang akan membutuhkan ruang personal yang lebih besar pada setting publik seperti di taman, plaza, dan lain-lain. Akan terjadi stress dan kegelisahan bila ruang ini dimasuki oleh orang lain apalagi yang belum dikenal, karena di dalam ruang publik ini terjadi aktivitas secara bersama-sama.

\section{METODE PENELITIAN}

Teori behavior setting merupakan teori terapan dari psikologi lingkungan yang mengidentifikasi fenomena perilaku individu dengan lingkunganya. Menurut Gifford (1997) behavior setting merupakan suatu unit ekologi kecil yang melibatkan tingkah laku manusia di dalamnya. Teori ini mempelajari sifat dasar lingkungan, dan membentuk perilaku yang sangat spesifik yang akan terjadi. Kehidupan manusia banyak dipengaruhi oleh lingkunganya, dimana lingkungan tersebut membentuk perilaku manusia dan juga sebaliknya manusia dapat merubah lingkungan sesuai dengan kebutuhanya. Barker dalam Laurens (2004, p.131) mengatakan bahwa behaviour setting disebut juga dengan "tatar perilaku" yaitu pola perilaku manusia yang berkaitan dengan tatanan lingkungan fisiknya. Senada dengan Haviland dalam Laurens (2004, p.131) bahwa tatar perilaku sama dengan "ruang aktivitas" untuk menggambarkan suatu unit hubungan antara perilaku dan lingkungan bagi perancangan arsitektur.

\section{HASIL, ANALISIS DAN PEMBAHASAN}

Berbicara mengenai ruang terbuka publik erat kaitannya dengan aktivitas penggunanya. Aktivitas juga erat kaitannya dengan perilaku manusia itu sendiri. Oleh karena itu berbicara mengenai ruang terbuka publik tidak terlepas dengan aspek perilaku para pelakunya.

Namun ada yang unik ketika melihat perilaku masyarakat di Kampung Kebangsren pada ruang public, dimana mereka mempunyai cara-cara unik untuk menyiasati kekurangan ruang terbuka public di Kampung Kebangsren. Banyak sekali ruang-ruang yang mereka ciptakan untuk tetap menjaga sifat social dan budaya asli pada masyrakat Kampung Kebangsren.

Terdapat beberapa area yang sering kali dijadikan sebagai tempat untuk warga beraktivitas pada ruang terbuka. Jenis ruang public di kampung Kebangsreng sebagai berikut:

1. Persimpangan Gang
Pada area ini pemuda dan juga orang tua sering berkumpul sekedar berbincang dan mengopi. Sesuatu hal yang unik dari kampung ini ialah masyarakat sering kali menjadikan pertigaan sebagai media bercengkrama dengan adanya warung atau hanya sekedar tempat tempat duduk. Peta Kampung Kebangsren ditunjukkan dalam Gambar 1 dan letak pertigaan ditunjukkan dalam Gambar 2.

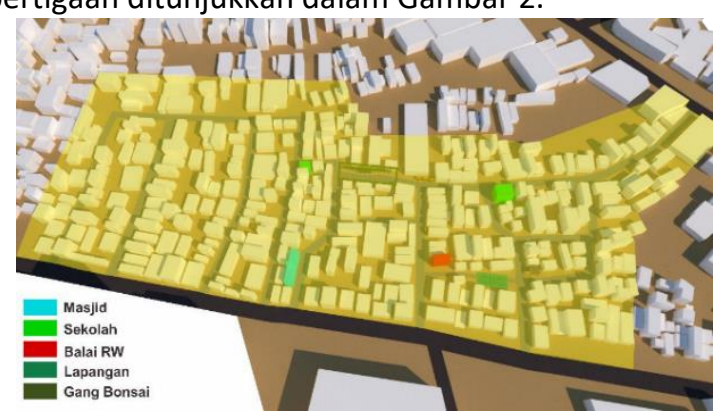

Gambar 1. Peta Kampung Kebangsren (sumber: dokumentasi dokumentasi penulis, 2019)

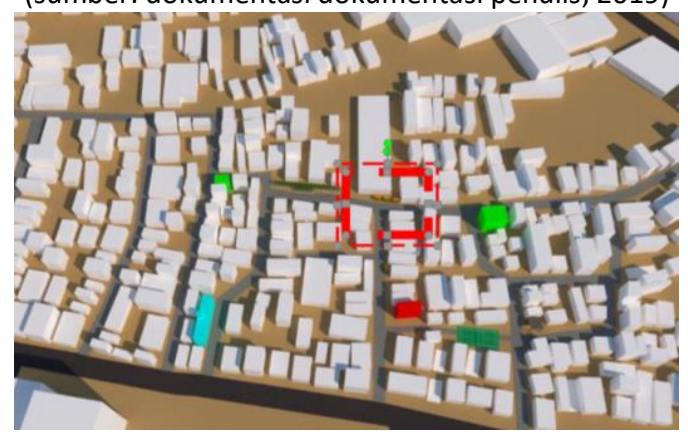

Gambar 2. Lokasi Persimpangan Gang

(sumber: dokumentasi dokumentasi penulis, 2019)

Data penelitian didapatkan berupa data aktivitas keseharian masyarakat Kampung Kebangsren pada area persimpangan gang dapat dilihat dalam tabel 1 , dan kondisi persimpangan gang dalam Gambar 3.

Table 1. Analisa Aktivitas di Persimpangan Gang

\begin{tabular}{|c|c|c|}
\hline $\begin{array}{l}\text { HARI \& } \\
\text { WAKTU }\end{array}$ & SENIN - JUMAT & SABTU - MINGGU \\
\hline $\begin{array}{c}\text { PAGI } \\
(07: 00- \\
09: 00)\end{array}$ & $\begin{array}{l}\text { Intensitas } \\
\text { masyarakat } \\
\text { kalangan ibu ibu, } \\
\text { berkumpul untuk } \\
\text { membelisayur dari } \\
\text { pedagang keliling } \\
\text { dan para ibu } \\
\text { mengasuh anak } \\
\text { kecilnya untuk } \\
\text { bermain main. }\end{array}$ & $\begin{array}{l}\text { Intensitas didominasi } \\
\text { oleh kalangan ibu ibu } \\
\text { dan juga anak anak yang } \\
\text { berkumpul untuk } \\
\text { sekedar bermain dan } \\
\text { berkumpul dikarenakan } \\
\text { para penjual makanan } \\
\text { ringan yang digemari } \\
\text { para anak kecil } \\
\text { berjualan di pagi hari } \\
\text { pada hari sabtu dan } \\
\text { minggu. }\end{array}$ \\
\hline $\begin{array}{c}\text { SIANG } \\
(12: 00- \\
14: 00)\end{array}$ & $\begin{array}{l}\text { Intensitas } \\
\text { masyarakat mulai } \\
\text { berkurang, karena } \\
\text { aktivitas masing } \\
\text { masing (bekerja). }\end{array}$ & $\begin{array}{l}\text { Tidak banyak } \\
\text { perubahan aktivitas di } \\
\text { siang hari. Siang hari } \\
\text { tetap didominasi oleh } \\
\text { anak kecil yang sedang } \\
\text { bermain. }\end{array}$ \\
\hline
\end{tabular}




\begin{tabular}{cll}
\hline HARI \& & SENIN-JUMAT & \multicolumn{1}{c}{ SABTU - MINGGU } \\
WAKTU & \multicolumn{1}{c}{ Terjadi peningkatan } & Pada sore hari para \\
& $\begin{array}{l}\text { intensitas pada titik } \\
\text { pemuda dan bapak }\end{array}$ \\
SORE & ini dari kalangan & mulai berkumpul di \\
$(16: 00$ & pemuda dan orang & warung \\
$-18: 00)$ & tua & \\
&
\end{tabular}
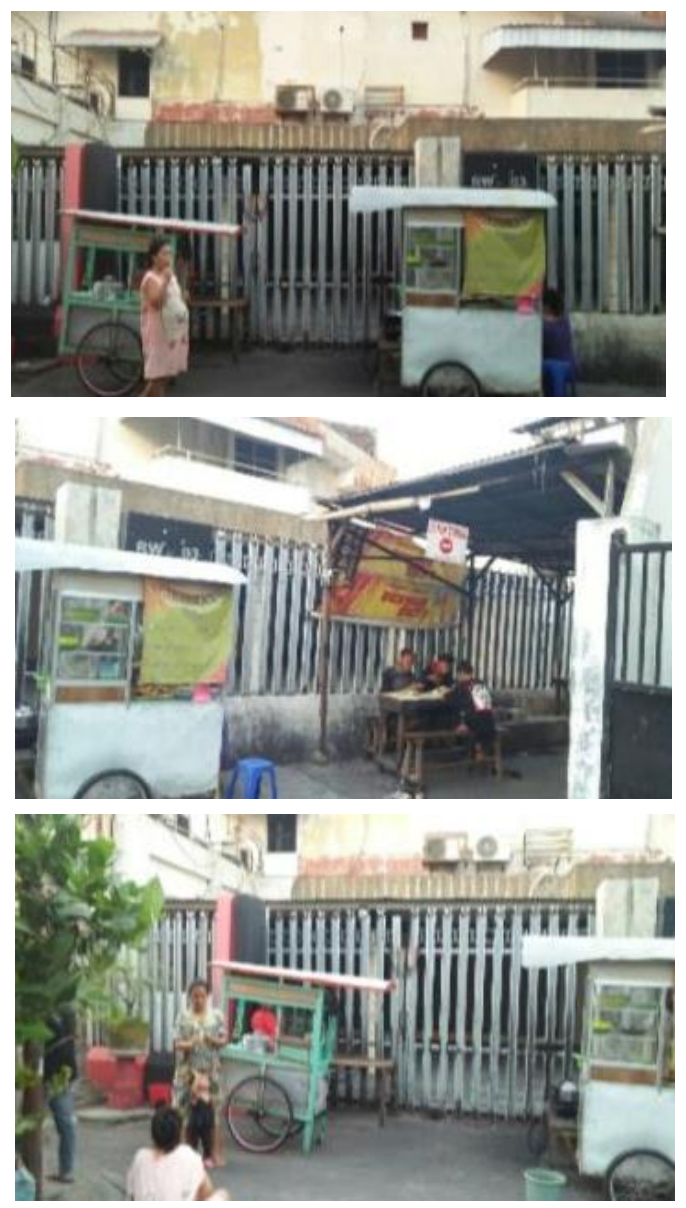

Gambar 3. Situasi Persimpangan Gang

(sumber: dokumen dokumentasi penulis, 2019)

\section{Lapangan Kampung}

Lapangan Kebangsren salah satu ruang terbuka public yang ada di Kampung Kebangsren. Lapangan ini seringkali digunakan sebagai tempat acara pada harihari besar, seperti lomba 17 Agustus, posyandu lansia, dan sebagainya. Pada area lapangan ini terdapat gazebo dan tempat untuk duduk-duduk di pinggir lapangan. Lokasi lapangan kampong terlihat di Gambar 4.

Hasil pengamatan terhadap kondisi fisik apngan kampong dan perilaku dan aktivitas masyarakat dalam kesehariannya dapat dilihat dalam tabel 2.

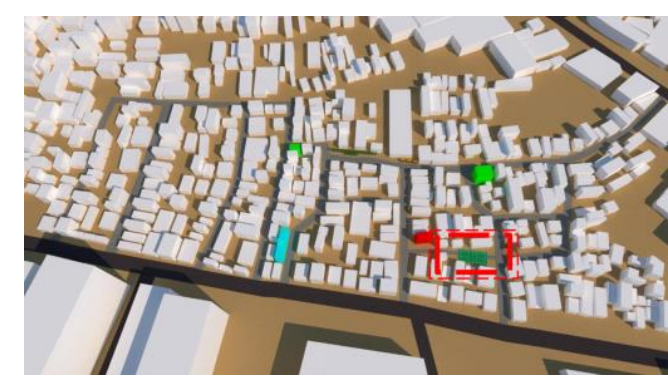

Gambar 4. Lokasi Lapangan Kampung

(sumber: dokumentasi dokumentasi penulis, 2019)

Table 2. Analisa Aktivitas di Persimpangan Gang

\begin{tabular}{|c|c|c|}
\hline $\begin{array}{l}\text { HARI \& } \\
\text { WAKTU }\end{array}$ & SENIN - JUMAT & SABTU - MINGGU \\
\hline $\begin{array}{c}\text { PAGI } \\
\text { (07:00 - } \\
09: 00)\end{array}$ & $\begin{array}{l}\text { Pada pagi hari } \\
\text { aktivitas yang } \\
\text { dijumpai adalah } \\
\text { banyak para orang } \\
\text { tua dan lansia yang } \\
\text { sedang berolah raga } \\
\text { meregangkan badan } \\
\text { dan juga ibu-ibu yang } \\
\text { sedang mengasuh } \\
\text { anaknya. }\end{array}$ & $\begin{array}{l}\text { Pada hari Sabtu dan } \\
\text { Minggu pagi lapangan } \\
\text { ini digunakan oleh } \\
\text { anak-anak untuk } \\
\text { bermain. Para } \\
\text { pemuda berkumpul di } \\
\text { gazebo yang ada di } \\
\text { area lapangan ini. } \\
\text { Pada hari da n } \\
\text { waktu tertentu } \\
\text { digunakan sebagai } \\
\text { tempat untuk } \\
\text { posyandu lansia. }\end{array}$ \\
\hline $\begin{array}{l}\text { SIANG } \\
(12: 00- \\
14: 00)\end{array}$ & $\begin{array}{l}\text { Pada siang hari } \\
\text { lapangan ini cukup } \\
\text { sepi karena para } \\
\text { pemuda dan orang } \\
\text { tua melakukan } \\
\text { aktivitasnya masing- } \\
\text { masing. Pemilik } \\
\text { rumah yang ada di } \\
\text { sekitar lapangan saja } \\
\text { yang duduk-duduk } \\
\text { dan bersantai pada } \\
\text { tempat duduk dan } \\
\text { gazebo yang ada di } \\
\text { sekitar lapangan. }\end{array}$ & $\begin{array}{l}\text { Tidak banyak } \\
\text { perubahan aktivitas di } \\
\text { siang hari, yang mana } \\
\text { tetap didominasi oleh } \\
\text { anak kecil yang } \\
\text { sedang bermain. }\end{array}$ \\
\hline $\begin{array}{c}\text { SORE } \\
(16: 00- \\
18: 00)\end{array}$ & $\begin{array}{l}\text { Terjadi peningkatan } \\
\text { intensitas pada waktu } \\
\text { sore, dimana para } \\
\text { pemuda dan orang } \\
\text { tua berkumpul dan } \\
\text { berbincang di gazebo } \\
\text { dan tempat duduk } \\
\text { yang ada di sekitar } \\
\text { lapangan ini. }\end{array}$ & $\begin{array}{l}\text { Pada sore hari para } \\
\text { pemuda dan anak- } \\
\text { anak banyak } \\
\text { dijumpai sedang } \\
\text { bermain dan } \\
\text { berolahraga di } \\
\text { lapangan. Sedangkan } \\
\text { para orang tua banyak } \\
\text { yang berkumpul dan } \\
\text { berbincang-bincang di } \\
\text { gazebo lapangan ini. }\end{array}$ \\
\hline $\begin{array}{l}\text { MALAM } \\
(19: 00- \\
21: 00)\end{array}$ & $\begin{array}{l}\text { Tidak banyak } \\
\text { perubahan intensitas } \\
\text { pada malam hari di } \\
\text { area ini. Banyak } \\
\text { dijumpai para } \\
\text { pemuda dan bapak- } \\
\text { bapak yang } \\
\text { berkumpul. }\end{array}$ & $\begin{array}{l}\text { Pada malam hari para } \\
\text { pemuda tetap } \\
\text { melanjutkan aktivitas } \\
\text { yang sama yaitu } \\
\text { berkumpul dan } \\
\text { bercanda di gazebo } \\
\text { lapangan ini. }\end{array}$ \\
\hline
\end{tabular}



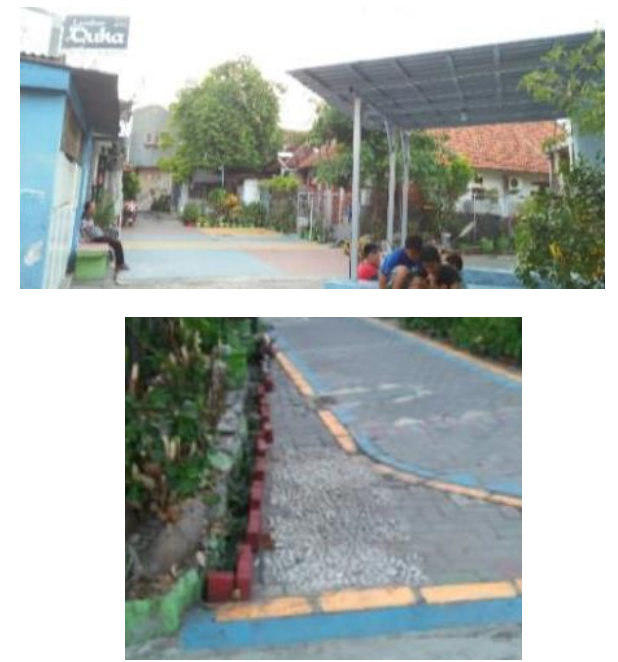

Gambar 5. Situasi Lapangan Kampung (sumber: dokumentasi penulis, 2019)

\section{Balai RW}

Aktivitas di Balai RW dilakukan setiap 2 pekan sekali di hari Minggu, berupa kegiatan rapat bersama anggota Karang Taruna Kampung Kebangsren. Kegiatan lain dilakukan pada malam minggu, dimana pemuda Karang Taruna berkumpul untuk sekedar bermain, ngobrol. Balai RW terlihat dalam Gambar 6 dan 7.

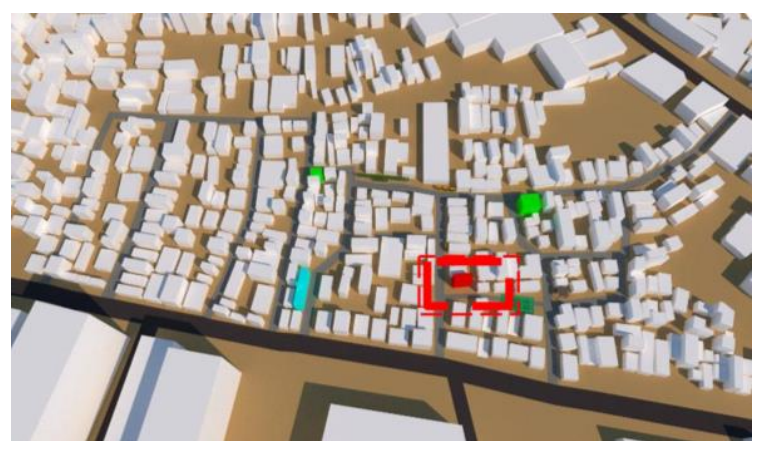

Gambar 6. Lokasi Balai RW

(sumber: dokumentasi dokumentasi penulis, 2019)

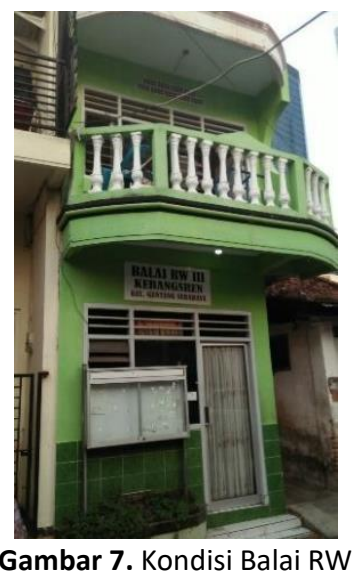

(sumber: dokumentasi dokumentasi penulis, 2019)

\section{Gang Bonsai}

Gang Bonsai merupakan sebuah gang yang sengaja diciptakan para penduduk Kampung Kebangsren sebagai ruang terbuka hijau dan sebagai gang iconic Kampung Kebangsren. Bonsai juga memiliki makna bahwa warga Kampung Kebangsren akan tetap menjaga keamanan kampung dan terus merawatnya layaknya merawat bonsai. Gang bonsai ini sengaja diciptakan dikarenakan untuk menjawab sebuah permasalahan kurangnya ruang terbuka hijau pada area Kampung Kebangsren. Lokasi gang bonsai ada di sisi utara kampong, seperti terlihat di Gambar 8.

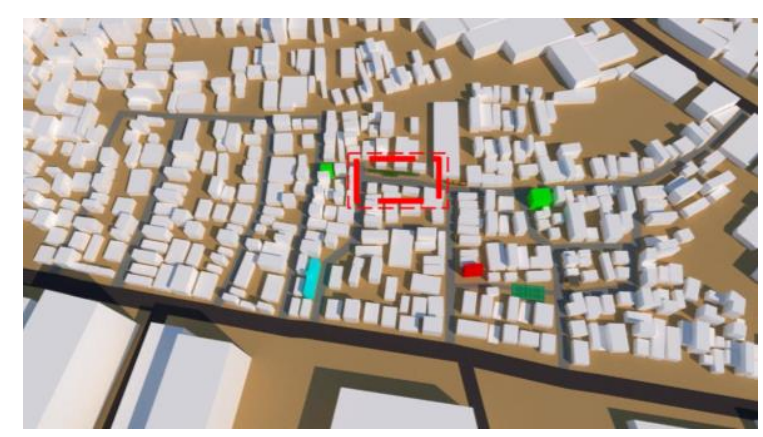

Gambar 8. Lokasi Gang Bonsai

(sumber: Dokumentasi penulis, 2019)
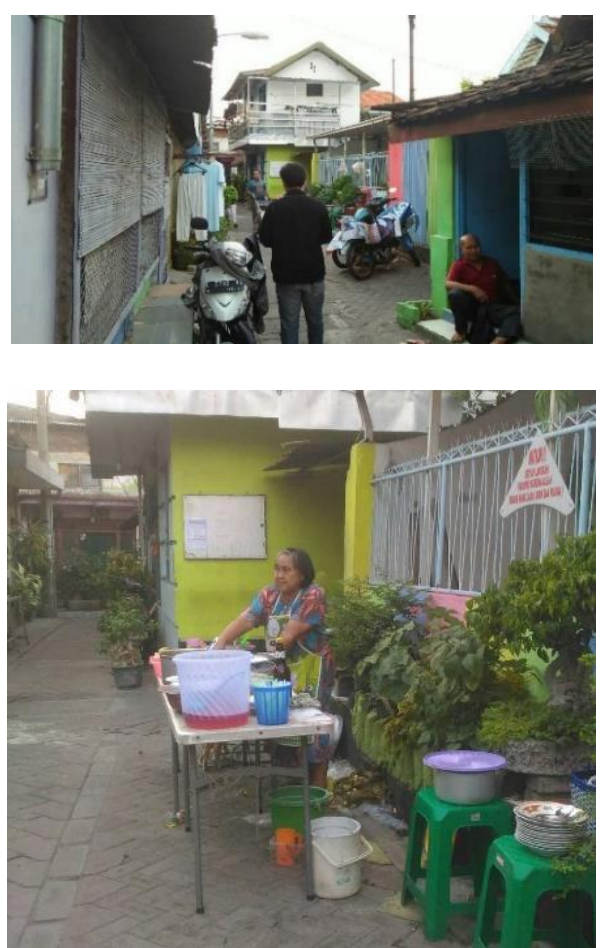

Gambar 9. Situasi Gang Bonsai

(sumber: Dokumentasi penulis, 2019)

Pada sore hari aktivitas yang paling terlihat di gang bonsai adalah berjualan makanan dan aktivitas duduk duduk dan bercanda atau ngobrol di antara warga kampong sambil bersantai di teras rumah. 


\section{Teras Rumah}

Berbicara dalam konteks perkampungan dimana sangat melekat hubungannya dengan kehidupan bersosialisasi yang tinggi. Warga Kampung Kebangsren yang memiliki lahan ruang terbuka yang sempit dan juga termasuk dalam kawasan slum dengan jalur kondisi sirkulasi (berupa gang) yang sempit dan rumah-rumah yang berhimpit, ternyata keadaan ini dimanfaatkan warga untuk lebih mendekatkan hubungan antar warga, dengan cara membuat tempat duduk pada bagian depan rumah, yang terbuat dari beton. Tempat ini dapat dikatakan juga sebagai ruang public yang muncul tidak denga sengaja. Di tempat ini warga bisa saling berinteraksi (lihat Gambar 10 dan 11).

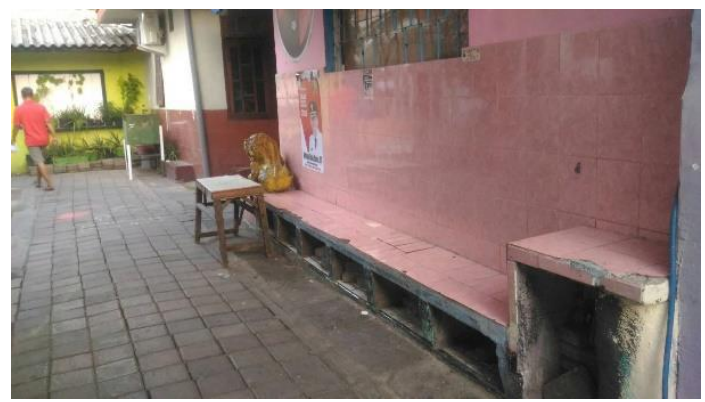

Gambar 10. Dudukan pada bagian luar rumah (sumber: Dokumentasi penulis, 2019)

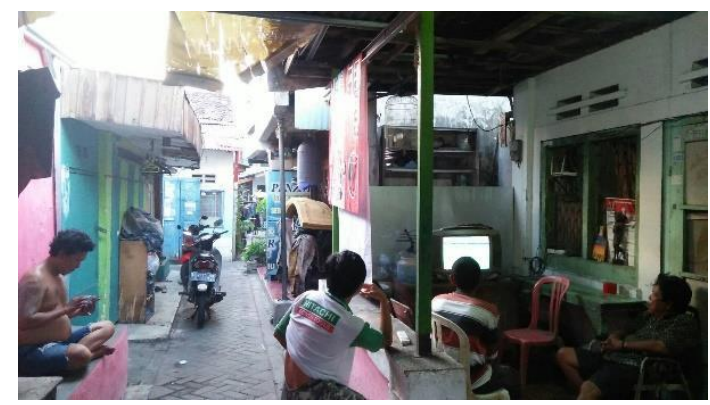

Gambar 11. Warga sedang menonton pertandingan sepak bola bersama di teras rumah (sumber: Dokumentasi penulis, 2019)

\section{KESIMPULAN}

Keterbatasan ruang terbuka public dan kecilnya sirkulasi jalan pada Kampung Kebangsren tidak menjadi masalah bagi masyarakat Kampung Kebangsren untuk melestarikan budaya sosisal dalam bermasyarakat. Warga Kampung Kebangsren berinisiatif menciptakan ruang terbuka publik untuk memenuhi kebutuhan tersebut.

Minimnya ketersediaan ruang terbuka public, membuat warga Kampung Kebangsren memanfaatkan teras rumah dengan sebagai ruang terbuka public. Warga membuat tempat duduk di depan rumah untuk tempat berkumpul. Selain itu pertigaan gang yang cukup luas memancing warga berinisiatif menciptakan warung sebagai wadah bagi para pemuda dan orang tua untuk berkumpul. Sehingga aktivitas masyarakat Kampung Kebangsren terbentuk dari hasil inisiatif atau ide-ide yang mereka ciptakan.

Dalam berinteraksi dan beraktivitas sehari - hari masyarakat membentuk wilayah atau daerah-daerah yang dianggap dapat memenuhi kebutuhan sosialnya. Pemanfaatan ruang yang digunakan untuk kepentingan pribadi adalah yang terdekat dengan tempat tinggal baik di bagian depan, samping atau belakang, dan pemanfaatan ruang yang bersifat publik digunakan sebagai kegiatan interaksi maupun kegiatan komersial.

Secara garis besar penciptaan ruang-ruang terbuka publik yang ada di Kampung Kebangsren juga memperhatikan aspek-aspek yang menunjang keberlangsungan aktivitas masyarakat pada ruang terbuka. Ruang terbuka tidak hanya dapat digunakan untuk aktivitas tertentu tetapi juga dapat digunakan untuk berbagai aktivitas lainya sehingga tidak monoton. Beberapa area yang tadinya tidak berguna, akhirnya dapat bermanfaat untuk memenuhi kebutuhan sosial dan psikologis masyarakat Kampung Kebangsren.

\section{UCAPAN TERIMA KASIH}

Ucapan terima kasih kepada seluruh pihak terkait yang telah membantu dalam dokumentasi penulisan jurnal ini dan juga kepada dosen pengampu Bu Wiwik Dwi Susanti yang telah memberi saran dan opsi selama dokumentasi dan penulisan, sehingga penulis dapat menyelesaikan penelitian dan publikasi ini.

\section{DAFTAR PUSTAKA}

Anita, J., Gustya, F., Erawati, L. R., \& Sukma, M. D. (2013). Kajian Terhadap Ruang Publik Sebagai Sarana Interaksi Warga di Kampung Muararajeun Lama, Bandung. REKA KARSA, 1(1).

Budiardjo, Eko, Djoko Sudjarto, 2005, Kota Berkelanjutan, Bandung, PT. Alumni, Cetakan II

Budiharjo, E. 1992. Sejumlah masalah perkampungan kota. Bandung: PT. Alumni

Darmawan, Soni., Utami, Tin Budi. (2018) Pola Pemanfaatan Ruang Terbuka Pada Pemukiman Kampung Kota, Vitruvian Jurnal Arsitektur, Bangunan, \& Lingkungan | Vol.7 No.3 Juli 2018 : 127-136

Haryanti, D. T. (2008). Kajian Pola Pemanfaatan Ruang Terbuka Publik Kawasan Bundaran Simpang Lima Semarang (Doctoral dissertation, program Pascasarjana Universitas Diponegoro). 
Effendi, D., Waani, J. O., \& Sembel, A.(2017). Pola Perilaku Masyarakat Terhadap Pemanfaatan Ruang Terbuka Publik diPusat Kota Ternate.

Hantono, Dedi. (2019) Kajian Perilaku Pada Ruang Terbuka Publik, Jurnal Nalars NALARs Jurnal Arsitektur Volume 18 Nomor 1Januari 2019: 4556

Hendrianto. 1997. Model Pembangunan Perumahan dalam peremajaan Permukiman Kumuh

Heryati. 2008. Identifikasi Kawasan Permukiman Kumuh Kota Gorontalo. Makalah disajikan dalam Seminar hasil Identifikasi Lokasi dan Penyusunan Rencana Pengembangan Kawasan Permukiman Kota Gorontalo, Departemen Pekerjaan Umum Direktorat Jenderal Cipta Karya, Gorontalo 6 Januari.

Laurens, Joyce Marcella. 2004, Arsitektur dan Perilaku Manusia. PT Grasindo, Jakarta

Rapuano, Michael 1964, Open Space In Urban Design, The Cleveland Development Foundation

Turner, John F. C., and Robert Fichter., 1972, Freedom to Build; Dweller Control of the Housing Process. New York: Macmillan.
Todaro, Michael P., 2004, Pembangunan Ekonomi Di Dunia Ketiga. Edisi Kedelapan. Jakarta: Erlangga. 